\title{
The grammaticalisation of definite articles in German, Dutch, and English: a micro- typological approach
}

\begin{abstract}
Sharing definite articles as a common feature, Germanic languages, however, diverge considerably with respect to these articles' functional domains. Restrictions concern generic uses on the one hand and combinations with proper names on the other, displaying both later stages in grammaticalisation. Taking three West Germanic languages into account, German, Dutch, and English, it is shown that the semantic-pragmatic extension proceeds along the hierarchy definite $>$ generic $>$ onymic with the spread singular $>$ plural generics and non-prototypical > prototypical proper names (i.e. with/without appellative heads) as intermediate steps. It will be argued that this development is most advanced in German, where both the generic and the onymic article are extensively used, which is not the case in English. Allowing for both the generic and the onymic article but with restrictions, definite articles in Dutch represent an intermediate stage of functional expansion.
\end{abstract}

Zusammenfassung: Aus einem Demonstrativ entstandene Definitartikel sind ein gemeinsames Charakteristikum der germanischen Sprachen. Trotz des gleichen Entstehungsweges bestehen klare funktionale Unterschiede; insbesondere divergiert der Gebrauch in generischen Kontexten und die Kombinierbarkeit mit inhärent definiten Eigennamen. Der Beitrag fokussiert, aus mikro-typologischer Perspektive, die funktionale Extension des Definitartikels in drei west-germanischen Sprachen (Deutsch, Niederländisch und Englisch). Es wird gezeigt, dass die Grammatikalisierung der Hierarchie Demonstrativ > Definitartikel > generischer Artikel > onymischer Artikel folgt, mit der Expansion Singular > Plural (Generika) sowie nicht prototypische > prototypische Eigennamen (d.h. mit/ohne appellativischem/n Kopf) als Zwischenetappen. Diese Entwicklung ist im Deutschen am weitesten fortgeschritten, gefolgt vom Niederländischen. Die meisten Restriktionen gelten für den Definitartikel im Englischen. 


\section{Introduction}

Definite articles are a common Central European feature. However, the fact that their functional domains diverge considerably even within Germanic languages became evident during a presidential debate in 2016, when Donald Trump provoked a discussion on racism only because of his usage of the definite article in English which would probably have gone unnoticed in German: ${ }^{1}$

The news website QARTZ (https://qz.com/) comments as follows in a gloss from October 11, 2016: ${ }^{2}$

Linguistics explains why Trump sounds racist when he says "the" African Americans

One of the littlest words in the English language gives the biggest clue about where Donald Trump's head is at: his use of the word "the."

In the second US presidential debate on Oct. 9, Trump promised, "I'm going to help the African-Americans. I'm going to help the Latinos, Hispanics. I'm going to help the inner cities. [Clinton has] done a terrible job for the African-Americans.” [...]

If Trump had said, "I'm going to help African-Americans," we'd assume he meant African-Americans in general - whichever ones need help. Under normal circumstances, saying "the African-Americans" would raise the question: Which AfricanAmericans? [...] he intends to refer to all African-Americans, and so "the" seems unnecessary. But it is doing something. It takes that plural, "African-Americans," and makes the group into more of an undifferentiated whole. [...] "The" makes the group seem like it's a large, uniform mass, rather than a diverse group of individuals. This is the key to "othering:" treating people from another group as less human than one's own group.

Trump's “the” works as a dog-whistle to disaffected rural white voters attracted to his message. [...]

A woman with African-American roots reacted as follows:

I REALLY need him to stop calling me "THE African-Americans" because ARE YOU KIDDING ME?

Definite articles represent a characteristic feature of (western) European, mainly Germanic, Romance, and Balkan languages. They may also be described as a

1 I wish to thank two anonymous reviewers for their insights and criticisms, which helped substantially improve the quality of this article.

2 Link to the article: https://qz.com/806174/second-presidential-debate-linguistics-explains-whydonald-trump-sounds-racist-when-he-says-the-african-americans/ (29-3-2018). Many thanks to Damaris Nübling for drawing my attention to this article. 
Euroversal $^{3}$ (e.g. Haspelmath 1998, 2001; Heine/Kuteva 2006). According to Dryer (1989), only a third of the languages of the world employ definite articles (125 out of about 400 languages) and less than 8\% (31 languages) use both definite and indefinite articles. With respect to the worldwide sample, the European language area stands out typologically in that up to $39 \%$ of European languages have definite and indefinite articles at their disposal, and an additional 15\% have developed definite articles only (cf. Heine/Kuteva 2006). ${ }^{4}$

The development of definite articles from demonstrative determiners has frequently been the focus of typological research (cf. Greenberg 1978; Lehmann 1995; Lyons 1999: 331-334; Heine/Kuteva 2006: $97 \mathrm{ff.}$.). In the framework of grammaticalisation theory special attention has been paid to the semantic-pragmatic expansion into new functional domains, which has been described as a gradual spread in a predictable manner. In his essential work, Greenberg (1978) distinguishes three main diachronic stages of development (cf. also Hawkins 2004; Heine/Kuteva 2006; de Mulder/Carlier 2011), as depicted in Figure 1.

\section{(DEMONSTRATIVE) $>$ DEFINITE ARTICLE > SPECIFIC ARTICLE > NOUN MARKER}

Fig. 1: Stages of grammaticalisation according to Greenberg (1978)

At Stage I the former demonstrative "becomes compulsory and has spread to the point at which it means 'identified' in general” (Greenberg 1978: 61). Unlike (discourse-)deictic demonstratives that are restricted to situational or anaphoric use (e.g. this/the book over there, I bought a book - this/the book), definite articles typically denote entities that are not immediately given (i.e. non-situational). Instead, uniqueness in the discourse is based on a larger context such as a prior conversation (e.g. Did you watch the film, finally?), general knowledge (the president referring to the current president) or "stereotypic 'frames' (a house : the door)" (Hawkins 2004: 85, cf. also Himmelmann 1997: 93-101 on anamnestic determiners). In the terms of Hawkins, definite articles must be unique within the "pragmatic set" (or "P-set") shared between speaker and hearer (cf. Hawkins 1978, 1991; cf. also Lyons 1980). Representing Stage II in Greenberg's hierarchy,

3 The term Euroversal was introduced by Kortmann (1997: 271-288), who focuses on morphosyntactic properties of adverbial subordinators.

4 More marginal article systems attested in European languages that deviate from the common western European type are described in Schroeder (2006), e.g. systems with two definite articles (northern European) and definite articles going back to possessive suffixes (eastern European); on northern European cf. also Dahl (2004). 
specific or "non-generic" articles include "non-definite specific uses" (Greenberg 1978: 62). Stage II articles denote individual referents that are not yet part of the shared pragmatic set of speaker and hearer. They are typically used when participants are newly introduced in the discourse with "instances of non-referential use" also being included (e.g. I eat ${ }^{*}$ the/an apple a day) (Greenberg 1978: 62; cf. also Himmelmann 1997: 101-109 and König 2018 for a critical discussion of specific articles as a further development of definite articles). Specific articles are characteristic of Niger-Congo and Austronesian languages (cf. Greenberg 1978: 62-68; Himmelmann 2001) but - with the exception of a Northern Swedish dialect ${ }^{5}$ (cf. Dahl 2004) - they are not attested in European languages, where the indefinite article takes over (e.g. EN I've got ${ }^{*}$ the cat/a cat, I need ${ }^{*}$ the/a new car; cf. Heine/ Kuteva 2006). Articles that developed into mere noun or gender markers represent the last step (Stage III) in Greenberg's cline, which implies that "the mass of common nouns now only have a single form" and that the article "no longer has any synchronic connection with definiteness or specificity" (Greenberg 1978: 69). Stage III-articles are not attested in European languages either. Nominalisation constitutes, of course, a central function of articles particularly in English (to run - the run, green - the green). Still, in the languages investigated, the definite article requires an individual referent that is identifiable by the hearer and it stands in opposition to the indefinite article (a/the run, a/the bright green). Figure 2 takes up Stages I-III according to Greenberg (1978) and provides English examples.

Considering different language families and types, mainly African but also Austronesian and Australian languages, the three stages distinguished within this "macro"-typological perspective appear less appropriate to describe grammaticalisation in the western European languages. Belonging to a small set of languages worldwide that have developed both definite and indefinite articles (less than 8\% in Dryer 1989's sample), European languages stand out in that the indefinite article takes over in the domain of specific reference (Stage II) (cf. also

5 As shown in Dahl (2004: 172f.), in a Northern Swedish dialect, the suffixed definite article occurs with referents that are specific but not identifiable by the hearer. The following example is provided:

Skellefteå (Västerbotten)

Hä gick skaplit att klaarsä,

it go:PST okay to survive

meda $\dddot{a}$ fanns rått-än å mus-än

as long as it exist:PST rat-DEF.PL and mouse-DEF.PL

'[The cat thinks:] It was kind of OK [to live in the forest], as long as there were rats and mice ...' 
Harris 1980: 81f.). Thus, for the European sprachbund and for the closely related West Germanic languages in particular, where uses typical of Greenberg's Stage II/III-articles hardly ever occur, a more fine-grained scale is needed.

referential

non-referential

\begin{tabular}{|c|c|c|c|}
\hline Stage 0 & Stage I & Stage II & Stage III \\
\hline DEMONSTRATIVE & DEFINITE ARTICLE & SPECIFIC ARTICLE & NOUN MARKER \\
\hline $\begin{array}{l}\text { The book over there is } \\
\text { mine. }\end{array}$ & $\begin{array}{l}\text { Did you buy the book, } \\
\text { finally? }\end{array}$ & $\begin{array}{l}\text { l've got *the cat. } \\
\rightarrow \text { I've got a cat. }\end{array}$ & -..- \\
\hline
\end{tabular}

Fig. 2: Greenberg's cline applied to Germanic languages (English)

Lyons (1999) compares the functional domains of definite articles in four European languages (English, French, Italian, and Greek) from a synchronic perspective. The following picture emerges, see Figure 3:

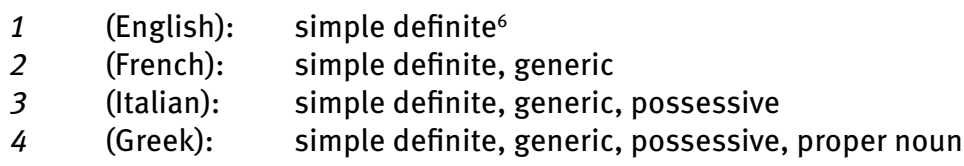

Fig. 3: Expansion in article use according to Lyons (1999: 337)

Of course, the purely synchronic data from only four languages have to be interpreted with caution. The figure is explicitly not intended as a universal implicational scale. Still, the data reflect the following diachronic evolution in the languages considered:

simple definite $>$ generic $>$ (possessive) $>$ proper noun

Although building on a small set of data only, this scale appears to be a promising starting point for the present purpose, all the more so since proper names are also taken into account. However, possessives will be discarded in the following analysis. They have to be the subject of future research.

6 "Simple definite" articles correspond to Stage I-articles in the terms of Greenberg. 
The development demonstrative > definite article is most straightforward and well documented (cf. Himmelmann 1997, 2001; Lehmann 1995; Szczepaniak 2011: 71-78). Less attention, in particular from a cross-linguistic perspective, has been paid so far to later stages in the grammaticalisation of articles, namely the gradual expansion to generic uses and, most notably, to proper names - a function generally subsumed under the so-called onymic article. Focusing on three closely related West Germanic languages, namely German, Dutch, and English, it will be shown that substantial differences exist with respect to the functional expansion of definite articles proposing the following scale, see Figure 4.

English: simple definite

Dutch: simple definite

German: simple definite generic propernoun

Fig. 4: Functional expansion in English, Dutch, and German (hypothetical)

The next section provides a short overview of the diachronic evolution by summarising the relevant research for German and English; for Dutch, diachronic data are unfortunately scarce.

\section{Stages of grammaticalisation: Diachronic overview}

\subsection{Diachronic overview: German}

In German, definite articles are missing in the earliest texts, but the demonstrative determiner grammaticalises in the course of the Old High German (OHG) period (750-1050) towards an incipient Stage I-article. The development from demonstrative determiner to definite article in Old High German (Stage $0>$ Stage I-article) has been the subject of several corpus-based studies (cf. Oubouzar 1992, 1997; Leiss 2000; Szczepaniak/Flick 2015; Flick 2017). In early Old High German, the determiner ther is restricted to discourse deictic functions and has to be interpreted as a demonstrative. For its transition to the definite article, anamnestic uses are considered as the starting point (cf. Himmelmann 1997: 93-101). At this point, definite reference is no longer based on the concrete situation or discourse context but on shared cultural or religious knowledge (e.g. OHG diu magd 'the virgin' for virgin Mary, diu skirft 'the writing' for the bible) (cf. Szczepaniak 2011: 71-73). From 
the 9th century onwards, non-situational uses are increasingly attested and OHG ther gradually evolves into a marker of definiteness. Being initially restricted to human referents, it expands along the animacy hierarchy human > animate > concrete $>$ abstract in the course of the OHG period (cf. Szczepaniak 2011: 74f.). The first instances of definite articles in generic contexts are attested as early as in the 9th century, in the OHG Tatian translation (ther man 'the human') but occur more regularly only from the 10th/11th century onwards. Selecting no individual entity but the class as a whole (e.g. the species man), generic articles referring to kinds pave the way for the expansion to indefinite or non-referential contexts (cf. chapter 3). As a last step, about 500 years later, from the late Early New High German period onwards (1350-1650), the definite article starts to spread to personal names in German vernaculars (16th century) (cf. chapter 4.1), where, similar to unique nouns (e.g. the moon), the article functions as a mere expletive marker (on the notion of an expletive article see Longobardi 1994; Gallmann 1997; Sturm 2005: 114-120; but Karnowski/Pafel 2005 for an opposing view). Figure 5 provides an overview of the diachronic development (cf. also Szczepaniak 2011: 78).

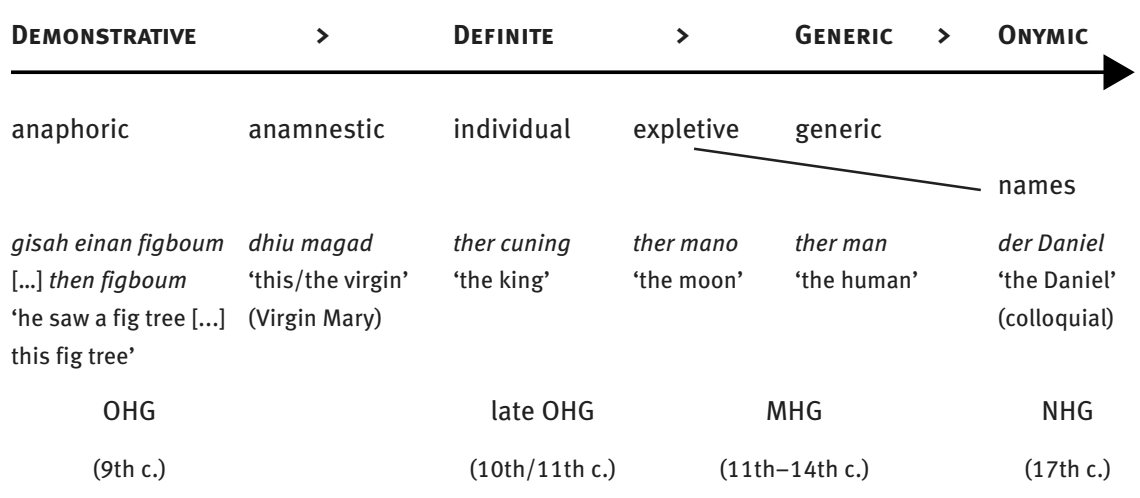

Fig. 5: Diachronic expansion of the definite article in German

\subsection{Diachronic overview: English}

The definite article in English has been the subject of numerous, mainly synchronic studies (e.g. Christophersen 1939; Hewson 1972; Carlson 1978; Hawkins 1978; Chesterman 1991; Lyons 1991, 1999). The major steps in the diachronic evolution presented below follow Hodler (1954), Hewson (1972), and the Cambridge history of the English language (Hogg (ed.) 1992; Blake 1992; Lass (ed.) 1999). For the early stages, the development from demonstrative to definite arti- 
cle, the evolution parallels that observed in Old High German. In the Old English period (500-1100), the fully inflecting OE determiner se (masc.), seo (fem.), pæt (neut.) is still restricted to discourse-deictic uses and expands only gradually to definite contexts. "In Old English many types of noun, and certain types of usage, show resistance to an article that has traces of demonstrative force" and seem "more like a mixture of demonstrative and article" (Hewson 1972: 18). In Middle English (1100-1500), when strong vs. weak adjectival inflection as an alternative marker of (in)definiteness got lost and the indefinite article emerged, the usage of articles comes to be further systematised in that a clear-cut distinction is established between both deictic that (< OE $p æ t)$ and non-deictic, invariant the (<OE se, seo) on the one hand and the definite (the) and the indefinite (a/an) article on the other hand (Blake 1992: 217). In Early Modern English (1500-1800), however, the definite article still tends to be left out in combination with abstract nouns (cf. Lass (ed.) 1999: 191f.). Definite articles with a generic reading are found only occasionally during the Old English period (OE Se lareow scal bion on his weorcum healic 'the/a teacher must excel in his works'; $c f$. Hogg (ed.) 1992: 176) but they occur more regularly by the end of the Middle English period with kind-referring singular nouns of the type the cat loves comfort (cf. Lass (ed.) 1999: 191). Also in Modern English, singular definite generics are missing with abstract nouns (EN * the life is beautiful vs. GE das Leben ist schön) (cf. Wandruszka 1969: 190; Schaden 2012) and mass nouns ( ${ }^{*}$ the wine, ${ }^{*}$ the rice) (cf. also chapter 3.1); definite plural generics are by and large restricted to nominalised adjectives (the poor, the French) (Lyons 1991, 1999: 189-193, but cf. also chapter 3 for corpus data). In combination with unique nouns (Pe heouene 'the heaven', pe sonne 'the sun'), definite articles can be found from the Middle English period onwards, but they did not survive in all instances in Modern English (the sun, the moon but ${ }^{*}$ the heaven, ${ }^{\star}$ the paradise, ${ }^{*}$ the hell ${ }^{7}$ ). Further restrictions concern prepositional phrases and the onymic article. In English, other than in Modern German, the article is often missing in prepositional phrases, in particular when reference is non-specific (EN she goes to church, he came after lunch vs. GE sie geht in die Kirche, er kam nach dem Mittagessen) (cf. Löbner 1985: 307). With only a few exceptions, mainly names of rivers (the Rhine), the onymic article is not available. Its use appears to be very restricted even if the name is premodified by an adjective ( ${ }^{*}$ the little Mary) (cf. chapter 4.2 for more details). For an overview see Figure 6.

7 Pointing to the divergent behaviour of *the heaven vs. the sky, Wandruszka (1969: 193) goes even further and interprets the religious terms heaven, paradise, and hell as proper names. 
To sum up, definite articles appear to be more restricted in use in English than in German. This holds true for their combinability with unique and abstract nouns and, most particularly, for generic contexts and in combination with proper names. The fact that the functional evolution is less advanced in English has already been pointed out by Curme (1922: 67):

A difference of development or conception in some cases leads to a different use of the article in the two languages: [...] it becomes apparent that English has preserved much better than German the old simple form of the noun without the definite article wherever it represents a person or thing single in kind, like a proper name.

Considering both the generic and the onymic article, in the following the functional expansion of the articles will be investigated in more detail.



Fig. 6: Diachronic expansion of the definite article in English

\section{Generic articles}

\subsection{Prototype- vs. kind-referring generics}

As has been pointed out in the vast body of literature on generics, basically both the indefinite and the definite article are available for generic reference but both of them are associated with different generic types, cf. (1):

(1) A tiger is striped.

Tigers are striped.

The tiger almost died out.
/ ${ }^{\star}$ A tiger almost died out.

/ Tigers almost died out.

/ ?The tiger is striped. 
The indefinite singular article operates on the level of individuals and singles out a prototypical member of its kind (e.g. a tiger is striped). ${ }^{8}$ For this type the term prototype-referring is introduced here. In the case of plural indefinites or bare plurals, all prototypical individuals are selected (Tigers are [generally] striped). Still, exceptions are allowed, which explains why plural indefinites are more widely applicable. ${ }^{9}$ The definite article, by contrast, is typically kind-referring and hence more restricted in use. Operating on a higher taxonomic level, it selects the class as a unit, e.g. the tiger, the lion etc. as definite uniform entities of the hyperonym mammals, and hardly allows for exceptions. Definite generics are the first choice in sentences with kind-level predicates (die out, be numerous), whereas indefinite generics are typically combined with individual-level predicates (be striped, be intelligent) (cf. Carlson 1978; Kratzer 1995; Barton/Kolb/ Kupisch 2015). ${ }^{10}$ The fact that definite articles and indefinite articles or bare plurals operate on different taxonomic levels can be illustrated by the following German examples taken from Laca (1992: 268), cf. (2):

$\begin{aligned} & \text { Die Deutschen } \\ & \text { The Germans drinken } \\ & \text { drink }\end{aligned}$ im Durchschnitt
Bier pro Jahr

\author{
?? Deutsche trinken im Durchschnitt 500 Millionen Liter \\ Germans drink an average of 500 million litres \\ Bier pro Jahr \\ beer per year \\ 'Germans drink an average of 500 million litres beer per year' (each German)
}

\footnotetext{
8 However, as Nickel (2012) pointed out, strong and weak generics have to be distinguished, involving majorities (e.g. tigers are striped) or indeed minorities (e.g. Dutchmen are good sailors). The first have also been referred to as definitional generics in the literature (cf. Krifka 2012).

9 The exact status of bare plurals is, however, unclear and has been controversially discussed in the literature, cf. e.g. Krifka (2004) on "Bare NPs: Kind-referring, indefinites, both or neither?" 10 In the literature, several terms have been introduced to refer to both types. Taking formal aspects (domains of definite vs. indefinite articles) into account, Gerstner/Krifka (1993) use the terms D-genericity vs. I-genericity (cf. also Platteau 1980 on "definite and indefinite generics"). Krifka et al. (1995: 2-3) distinguish between "kind-referring NPs" (The potato was first cultivated in South-America) and "generic sentences" (A potato contains vitamin C, amino acids, protein and thiamine.), cf. also Behrens (2000: 6-8) for a critical discussion. For the present purpose, however, the distinction prototype- vs. kind-referring seems most straightforward.
} 
In the first case, the definite article evokes a collective reading 'Germans all together drink about 500 million litres beer a year', which is not that much. ${ }^{11}$ The second example, however, implies a distributive reading and would require every single German to drink this quantity individually.

Basically, four options exist for generic NPs, but not all of them are likewise available in all three languages considered. Whereas productive definite singular generics represent a common feature, this is not the case for plural generics. In English, Gerstner/Krifka (1993: 967) ascribe definite generics “a rather marginal status”. Likewise, Hawkins (2004: 85) states that

German has gone further than English and regularly uses the definite article with generic plurals where English does not: er zieht den Rosen die Nelken vor (he prefers Def+Dat+Pl roses Def $+\mathrm{Acc}+\mathrm{Pl}$ carnations) 'he prefers carnations to roses'. He prefers the carnations to the roses in English suggests pragmatically identifiable sets of each.

Even though far from being "regularly" used in all contexts as assumed by Hawkins, definite plural generics are indeed much more common in German compared to English, which will be shown in the next section. To start, Table 1 compares the inventories for generic reference in English, Dutch, and German following the respective standard reference grammars (Quirk et al. 1999; Duden 2016; ANS).

Table 1: Availability of generic articles in English, Dutch, and German according to the standard grammars

\begin{tabular}{llll}
\hline & English & Dutch & German \\
\hline $\begin{array}{llll}\text { prototype- } \\
\text { referring }\end{array}$ & A tiger is striped. & Een tijger is gestreept. & Ein Tiger ist gestreift. \\
\cline { 2 - 4 } & Tigers are striped. & Tijgers zijn gestreept. & Tiger sind gestreift. \\
\hline kind-referring & $\begin{array}{l}\text { The tiger is threatened } \\
\text { with extinction. }\end{array}$ & $\begin{array}{l}\text { De tijger dreigt uit te } \\
\text { sterven. }\end{array}$ & $\begin{array}{l}\text { Der Tiger droht auszuster- } \\
\text { ben. }\end{array}$ \\
\cline { 2 - 4 } & $\begin{array}{l}\text { *The tigers are } \\
\text { threatened with } \\
\text { extinction. }\end{array}$ & *De tijgers dreigen uit & ?Die Tiger drohen auszu- \\
& te sterven. & sterben. \\
\hline
\end{tabular}

In the singular, definite NPs are common and constitute the first choice for kindreference - at least when combined with count nouns (the tiger, the potato). As

11 In fact, Germans consumed 84.6 million hectolitre in 2018, which, on average, corresponds to 102 litre each (cf. https://de.statista.com, last accessed: 7-10-2019). 
for human referents (nationality terms), singular generic NPs are grammatical in German, but involve a contemptuous reading and are therefore rather disfavoured (cf. Duden 2016: 295, § 390). In combination with mass (rice) or abstract (love) nouns definite singular generics are effectively more restricted and indeed ungrammatical in English ( ${ }^{*}$ the rice, ${ }^{*}$ the love). In Dutch, they are hardly acceptable for mass nouns (??de rijst), but regularly occurring with abstract nouns (de liefde). In German, both mass and abstract nouns take the definite article (der Reis, die Liebe). However, as a reflex of former anaphoric uses, generic articles are better accepted in the singular and in subject position - a restriction that is best described as a phenomenon of 'persistence' in the terms of Hopper (1990, 1991). The spread to (generic) object NPs constitutes a characteristic feature of languages representing an advanced stage of article grammaticalisation, such as in French for example, cf. (3):

(3) EN Rice was introduced in Europe in the 10th century. I like rice.

DU ??De rijst was was geïntroduceerd in Europa in de 10de eeuw. Ik hou van rijst.

GE Der Reis wurde im 10. Jahrhundert in Europa eingeführt. Ich mag Reis.

FR Le riz a été introduit en Europe au 10ième siècle. J'adore le riz.

Further restrictions concern definite plural generics that are not available in English so that bare plurals (indefinite plurals) are chosen instead. However, definite plurals are exceptionally allowed for nouns derived from adjectives (the poor, the rich), including nationality terms such as the French, the Chinese (cf. Lyons 1991). In those cases, the definite article first of all functions as a noun marker and is obligatorily used both in the singular and in the plural, which allows Lyons (1991: 105) to conclude: "So we have two types of plural generic: the indefinite restricted to nouns, and the definite restricted to adjectives." (Cf. also Lyons 1999: 181ff.) In the Dutch standard reference grammar the definite plural is marked as doubtful ("twijfelachtig") (cf. ANS, section 14.3.2). What is more, unlike in French, where the definite article is the first choice for generic reference (cf. Laca 1992; Lyons 1999: 51), in the other languages definite plural generics are restricted to human referents, mainly nationality terms (cf. chapter 3.2), cf. (4):

(4) EN Books/Cats are my greatest passion.

DU Boeken/Katten zijn mijn grootste passie.

GE Bücher/Katzen sind meine größte Leidenschaft.

FR Les livres/Les chats sont ma meilleure passion. 
In order to obtain a more complete picture of the use of definite articles in generic sentences in the three languages considered, a small corpus study has been conducted. The results will be presented in the following section.

\title{
3.2 Generic articles: Corpus data
}

Generics have been the subject of several corpus-based studies, most notably generics in English. Recent data on German and English, among others, are provided in Behrens (2000); generics in Dutch have been extensively studied in Oosterhof (2008); plural generics in German by Barton/Kolb/Kupisch (2015) and, from a language learners' perspective, in Kupisch/Barton (2013) and Kupisch/ Pierantozzi (2010). In her contrastive study on generics in German, English, French, Hungarian, and Greek based on the story "Le petit prince" and its translations, Behrens (2000: 23) concludes that in English

\begin{abstract}
the use of the definite article is significantly more weakly attested than in the other languages. More precisely, the percentage of definite phrases in English both in the singular $(11,24 \%)$ and in the plural $(24,42 \%)$ is approximately twice as low as the percentage of definite phrases in the other languages.
\end{abstract}

In addition, what is emphasised is the exceptional prominence of the bare plural in English. Barton/Kolb/Kupisch (2015) investigated the semantics of plural generics in German on the basis of acceptability judgement tasks. Their results support the claim that in German, besides bare subjects with an acceptability of $99.5 \%$, definite articles are also accepted in the plural (67.7\%), in particular when referring to kinds (kind-level 84.9\% vs. individual level: 61.9\%). Also, taking sociolinguistic aspects into account, age has been identified as a decisive factor: Older participants accepted significantly more definite plural generics than younger ones and, moreover, the preference for definite plural generics in kind-referring sentences declined with age. Based on modern Dutch corpora, spoken and written (INL-corpora, CONDIV-corpus) ${ }^{\mathbf{1 2}}$, Oosterhof's (2008) findings emphasise an equally strong correlation between kind-reference and the use of definite articles for Dutch. In combination with the kind predicate uitsterven/uitgestorven 'die out/died out', the percentage of definite articles amounts to 38\% (singular definites) and 47\%

12 INL-corpora = Corpora of the Instituut voor Nederlandes Lexicologie (http://corpushedend aagsnederlands.inl.nl/) (29-3-2018); CONDIV-corpus = corpus of the project Lexicale variatie in het Standaardnederlands. Convergentie/divergentie en standaardisering/substandaardisering in Nederland en Vlaanderen. 
(plural definites) respectively, whereas indefinite singular NPs (3\%) and bare plurals (13\%) are underrepresented (Oosterhof 2008: 79-82). Another study conducted on the basis of corpora and questionnaires focused on nationality (e.g. Italiaan 'Italian', Brazilaan 'Brazilian') and animal terms (e.g. orang oetan 'orang-utan', zeehond 'seal') in generic sentences (both, however, erroneously classified as nationality names and animal names ${ }^{13}$ ). Considering also areal factors (Netherlands vs. Belgium), the collected data reveals, first, a higher overall percentage of the generic article in the Flemish area (Belgium) and second, a significantly higher acceptance of singular definites in combination with animal terms (animal vs. nationality terms: NL 39\% : 13\%, BE 32\% : 18\%); conversely, plural definites occur more frequently with nationality terms (animal vs. nationality terms: NL: $4 \%: 21 \%$, BE: $3 \%: 25 \%$ ). Ranging between $48 \%$ and $64 \%$, bare plurals are, however, preferred in all subsets of data (cf. Oosterhof 2008: 103).

In order to directly compare the acceptance of the generic article in the three languages considered, data was collected from the COW-corpus, ${ }^{14}$ a web-based corpus with sub-corpora for English (ENCOW), German (DECOW), and Dutch (NLCOW) (cf. Schäfer/Bildhauer 2012; Schäfer 2015). A first query conducted concerned the items 'citizen', 'reader', and 'voter' all of which refer to the nature of citizens/readers/voters rather than to individuals and can therefore be classified as kind-referring generics typically involving definite singular NPs. A second query conducted in all three corpora focused on nationality terms. Referring to prototypical individuals, they are typically associated with plural indefinites. To obtain a maximum of generic sentences and to limit at the same time the total number of hits, both queries were restricted to items followed by a finite form of 'to be' (e.g. 'citizen is/citizens are'). In the present analysis, the first 200 hits of each query were taken into account and, in a second step, all sentences with a generic

13 Undoubtedly, animal and nationality terms share some properties with proper names (e.g. some kind of name-giving act for newly discovered species). Still, both of them behave like typical count nouns grammatically, do not refer to individuals and, what is most striking, they clearly have a denotative meaning. Accordingly, unlike proper names, they are not applicable to any entity in the world, but the object requires certain properties for being successfully referred to as orang-utan for example.

14 The COW-corpus (= Corpora from the Web) is a web-based corpus with linguistic annotation comprising texts from a wide range of genres (e.g. press, comments, interviews). The subcorpora used for the present study are composed as follows: DECOW14: 20,495,087,352 words/17,147,104 (Austrian, German, and Swiss German) documents; NLCOW 6,887,226,290 words/5,468,755 (Dutch and Flemish) documents; ENCOW14: 16,821,840,292 words/9,216,176 documents representing 'World Englishes' (see also http://corporafromtheweb.org/ (last accessed: 3-7-2019) for more details). 
interpretation were extracted using the test criteria for genericity defined in Krifka et al. (1995). The results are presented in Figures 7-8:

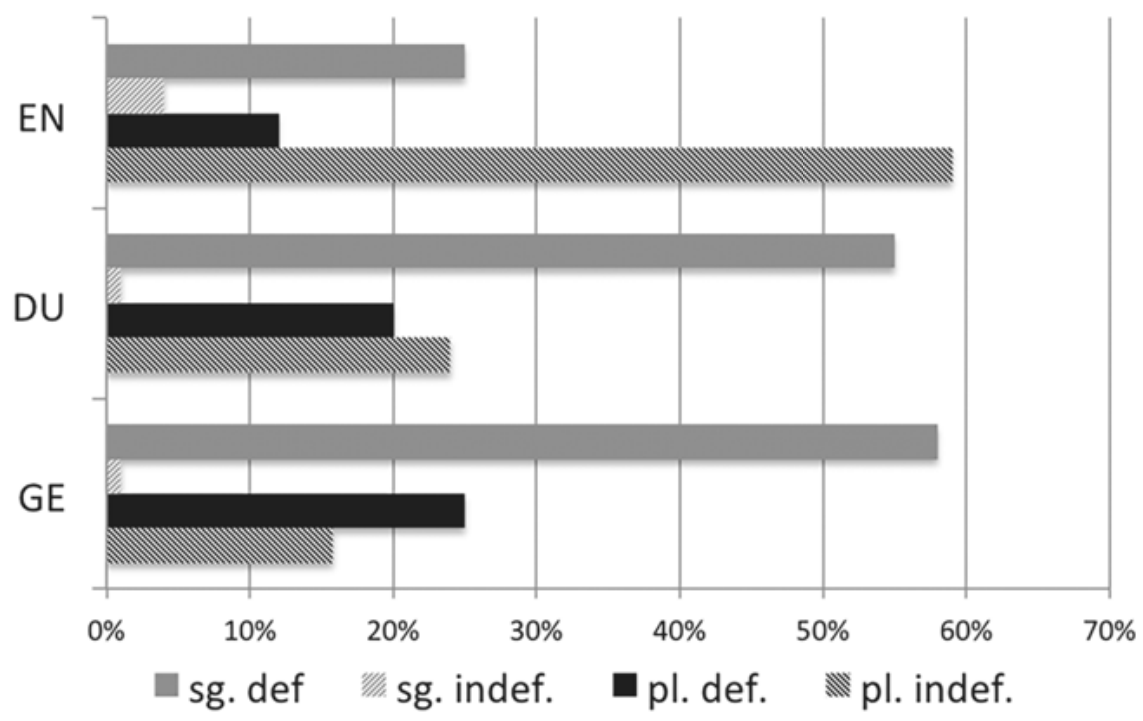

\begin{tabular}{|l|l|l|l|}
\hline & English & Dutch & German \\
\hline I. & The citizen is entitled to ... & De burger is bevoegd ... & Der Bürger ist berechtigt ... \\
\hline II. & A citizen is entitled to ... & Een burger is bevoegd ... & Ein Bürger ist berechtigt ... \\
\hline III. & The citizens are entitled to ... & De burgers zijn bevoegd ... & Die Bürger sind berechtigt ... \\
\hline IV. & Citizens are entitled to ... & Burgers zijn bevoegd ... & Bürger sind berechtigt ... \\
\hline
\end{tabular}

Fig. 7: Generic article: Reference to kinds $(n=401)$

According to the data presented in Figures 7-8, definite generics are most appropriate in the singular when referring to homogenous groups ('citizens', 'readers', 'voters') but significant differences can be observed with respect to the languages considered. Amounting up to 58\% and 55\% respectively in German and Dutch, definite singular NPs constitute the first choice when referring to kinds, which is clearly not the case for the English counterparts with a total of only $25 \%$ and with bare (indefinite) plurals being preferred instead (59\%). Reference to kinds is also possible with definite plurals and provides, by and large, the same general picture: Again, the highest ratio is attested for German (25\%) followed by Dutch $(20 \%)$ and finally English (10\%). In combination with nationality terms denoting 
a group of individuals a divergent picture emerges: Definite singulars are scarce (EN 0\%, DU 1\%=2x, GE 8\%=12x) and, in the few cases attested, they imply a negative, stereotyped reading, $\mathrm{cf}$. (5).



sg. def $\quad$ w/ sg. indef. $\quad$ pl. def. $\quad \mathbb{N}$ pl. indef.

\begin{tabular}{|l|l|l|l|}
\hline & English & Dutch & German \\
\hline I. & *The Americ. is proud of ... & *De Amerikaan is trots op ... & Der Amerik. ist stolz auf ... \\
\hline II. & An American is proud of ... & Een Amerik. is trots op ... & Ein Amerik. ist stolz auf ... \\
\hline III. & The Americ. are proud of ... & De Amerik. zijn trots op ... & Die Amerik. sind stolz auf ... \\
\hline IV. & Americans are proud of ... & Amerikanen zijn trots op ... & Amerikaner sind stolz auf ... \\
\hline
\end{tabular}

Fig. 8: Generic article: Reference to prototypical individuals (nationality terms) $(n=476)$

(5) DU We weten het allemaal heel zeker, de Amerikaan is oppervlakkig 'We know it all for sure, Americans are superficial.'15

GE der Amerikaner ist kulturell eben sehr tief stehend 'Americans simply are culturally underneat'"16

15 https://www.amerika.nl/amerika/reisgids/cliches-amerika/amerikanen-zijn-oppervlakkig/ (last accessed: 3-7-2019).

$16 \mathrm{http}: / /$ nachtkritik.de/index.php?option=com_content $\% 26$ task=view $\% 26 \mathrm{id}=3417 \% 26$ Itemid=40 (last accessed: 14-9-2019). 
Definite plurals, by contrast, are frequently attested and turn out to be the first choice in German (pl. def. 66\%, pl. indef. 22\%) and, what is surprising, also predominate in Dutch (pl. def. 51\%, pl. indef. 45\%). In English, where again bare plurals represent by far the preferred option (68\%), definite plurals achieve the lowest percentage, but still amount up to $32 \% .{ }^{17}$ Thus, definite plural NPs appear to be rather unmarked in German where they constitute the first choice (cf. also 67.7\% acceptance in Barton et al. 2015). Their English counterparts, however, are bare plurals. In Dutch, definite and bare plurals are equally accepted, which may point to a transitional state, such that the definite plural is about to be established as the unmarked form. However, the Dutch data presented in this study diverge considerably from the data provided in Oosterhof (2008), where definite plurals of nationality terms are less frequently attested amounting only up to $21 \%$ (NL) or $25 \%$ (BE) respectively.

With respect to a possible semantic load, a closer look at the data reveals that the proportions of definite plurals vary significantly for each research item. In German and Dutch, the total amount of definite articles is much higher when referring to 'Americans' and 'Frenchmen', whereas for 'Europeans' indefinite plurals take over (def. pl.: 'Frenchmen' GE 84\%, DU 62\%, 'Americans' GE 74\%, DU 56\%, 'Europeans' GE 45\%, DU 27\%). In English, definite plural generics achieve the highest percentage for 'Germans' (52\%), but are less frequent for 'Europeans' (29\%) and scarce for 'Americans' (10\%). ${ }^{18}$ Thus, being rather avoided for self-reference, definite generics predominantly refer to foreign nationalities (GE die Franzosen, die Amerikaner vs. (die) Europäer; DU de Fransen, de Amerikanen vs. Europeanen; EN the Germans vs. Europeans, Americans). These findings point to the fact that, in all three languages considered, definite generics (partially) retained their emphatic character and may involve a contemptuous reading and the notion of "othering" - a connotation that predominates in English, but is also present in Dutch, cf. (6).

\footnotetext{
EN But it is not against the Germans that we hold our primary grudge. ${ }^{19}$

DU De Amerikanen zijn verantwoordelijk voor de meeste oorlogen ter wereld.

'Americans are responsible for most of the wars worldwide. ${ }^{20}$
}

17 Possible differences with respect to the different 'Englishes' have to be the subject of future research based on a larger set of data.

18 For the English data, it has kept in mind, however, that several Englishes are included in ENCOW. $19 \mathrm{http} / / /$ home.comcast.net/ eo9066/1944/44-01/TL26.html (last accessed: 14-9-2019).

$20 \mathrm{https} / / /$ blog.thesilvermountain.nl/krachtenbundeling-edelmetaal-centrum-amsterdam/ comment-page-5/ (last accessed: 3-7-2019). 
To sum up, whereas indefinite singulars and, most notably, bare plurals constitute typical candidates for generic interpretation, the use of definite articles appears to be more restricted in earlier stages of grammaticalisation, namely to kindreference in the singular (the tiger, the teacher). In the plural, definite generics evoke a contemptuous reading when combined with nationality terms. In conjunction with the bleaching of deictic force during the process of grammaticalisation, the taxonomic interpretation weakens and definite generics gradually expand to groups of individuals. As has been shown, this development is most advanced in German, whereas English represents the other extreme with deictic force and the notion of "othering" still being prevalent.

\section{Onymic articles}

\subsection{Diachronic development}

\subsubsection{German}

As has been shown in chapter 2, the onymic article marks an advanced stage in grammaticalisation. Its rise in combination with personal names in German has been the subject of recent research. Onymic articles emerge in the late Early New High German period (16th/17th century) and spread from the southeast to the north triggered by case as one crucial factor among others (cf. Behaghel 1923: 52f.; Schmuck/Szczepaniak 2014; Schmuck forthc.). Disregarding name class, names combined with attributive adjectives exhibit the onymic article significantly earlier, obligatorily from the Middle High German period onwards and, what is remarkable, also unmodified names of rivers (Paul 1919: 180). For early attestations of the onymic article in combination with personal names and names of rivers cf. (7) and (8):

(7) Song of Anno (end of 11th century):

Von demi gezûgi des stiphtis Worti diu Semîramis / From the material of this building / fashioned the Semiramis / 'From the material of this building/Semiramis fashioned'

Die burchmura viereggehtich.

The town wall quadrangular.

'The town wall quadrangular.' 
(8) Tannhäuser, 13th century

Rome bi der Tiver lit, der Arne get für Pise

Rome near the Tiber is located, the Arno goes in front of Pisa

'Rome is located near the Tiber, the Arno flows through Pisa'

Paris bi der Seine lit, diu Musel get für Metzen

Paris near the Seine is located, the Moselle goes in front of Metz

'Paris is located near the Seine, the Moselle flows through Metz'

In combination with personal names, the onymic article is nowadays extensively used in southern German dialects including Swiss German and Austrian-Bavarian, where names combined with the onymic article in fact represent the unmarked option. It is rather its omission that is effectively felt as inconvenient (e.g. Nübling/Fahlbusch/Heuser 2015: 123-124). In the north, by contrast, it is the definite article that, depending on the context, may elicit a derogatory connotation and has remained uncommon up to the present (Werth 2014). Yet, the unmarked use of the onymic article currently spreads in colloquial speech proceeding from the south to the north with central German as a transitional area (cf. Bellmann 1990; Longobardi 1994: 653f.; Eichhoff 2000; Duden 2016: 301, §398; Werth 2015).

\subsubsection{Dutch}

Similar to their German counterparts, in Modern Dutch names combined with an attributive adjective obligatorily take the onymic article (de kleine Jan 'the little Jan') that, in southern (Flemish) dialects, appears regularly from the Middle Dutch period onwards (13th century) (cf. also van der Horst 2008, I: 843f.). Also in Middle Dutch, instances of bare, unmodified names combined with onymic articles are occasionally attested, cf. (9)-(11):

(9) Rijmbijbel, West-Flanders 1285:

Maria, des mijnders IJacobs moeder

Mary, the younger Jacob's mother

'Mary, the mother of Jacob the Younger's'

(10) Rijmbijbel, West-Flanders 1285:

Martha beclaghede die Magdalene

Martha deplored the Magdalena

'Martha deplored Magdalena' 
(11) Van onser vrouwen gheslachte, East-Flanders 1290:

$\begin{array}{llll}\text { Dat was ihesus dier } & \text { marien } & \text { kint } \\ \text { That was Jesus the-GEN } & \text { Mary-GEN } & \text { child } \\ \text { 'That was Jesus, Mary's child' } & & \end{array}$

Standard Dutch lacks the onymic article with unmodified personal names. However, onymic articles are characteristic of Flemish dialects and a south-north decline of article use similar to the situation in the German-speaking area can be observed. The following examples are extracted from the The Dynamic Syntactic Atlas of the Dutch dialects ${ }^{21}$ ), cf. (12):

\section{SAND sentence 286}

Herinneren jullie je nog dat we Jan op de markt gezien hebben?

'Do you still remember that we have seen Jan on the market?'

a. Brabant, b. Limburg

a. Wette gelle nog da we de Jan op de met emme gezien?

b. Wit ier nog dat y'a d'r Jan óp d'r maar zoge? Know you still that we the Jan on the market once saw /

(have) seen?

As a striking fact, onymic articles are far more common with names of men as pointed out by van Langendonck (2007: 158): "In Dutch (Flemish) dialects the article $d e$ 'the' is used before men's names and sometimes before women's names to express familiarity with respect to the name bearer, e.g., de Jan 'the John', de Marie 'the Mary'."

According to van de Ven/Govaart (1917), the onymic article combined with personal names appears in Brabant already in the 17th century (de Jans, den Theum $^{22}$ ) and at that time equally induces a familiarity reading ("iets familiaars").

Similar to German and English, names of rivers regularly require the onymic article in modern Dutch (de Rijn, de Moezel), with the first instances dating back to Middle Dutch (14th/15th century), cf. (13):

21 The Dynamic Syntactic Atlas of the Dutch dialects (DynaSAND) is an on-line tool for dialect syntax research available at http://www.meertens.knaw.nl/sand/ (last accessed: 3-7-2019).

22 Similar to definite articles in combination with common nouns, the onymic article equally reflects the Flemish "accusativism" (cf. van Loon 1989), i.e. the phonologically conditioned alternation of $d e$ and den (i.e. former accusative article) with the latter being used when the noun/ name starts with a vowel or with one of the consonants $h, b, d, t$ or $r$ (e.g. de Jan vs. den Alex). I am grateful to Ann Marynissen and to an anonymous reviewer for drawing my attention to this aspect. 
(13)

Reinaerde van den vos 1401-1410:

Tusschen dier Elve entjer Zomme

Between the Elbe and=the Somme

\subsubsection{English}

In modern English, personal names are typically undetermined. Sporadic occurrences of the onymic article with bare (unmodified) names concern honorific articles such as the Talbot, the Douglas (cf. Poutsma 1914: 570f.), with Donald Trump's nickname the Donald representing a contemporary case in point. Crucially, the article is also absent with premodifiers (little Eric, poor Mary), even though certain adjectives exhibit the onymic article (the inimitable/ill-fated/ unfortunate John Smith). According to the literature, personal names remain undetermined if the adjective has an "emotive colouring" (old Mrs. Fletcher, poor Charles), whereas "[i]n a more formal rather stereotyped style, the adjective is placed between the and a personal name" (e.g. the inimitable Henry Higgins) (Quirk et al. 1999: 290; cf. also Huddleston/Pullum 2002: 519f.). In other words, the article is absent when restrictive, name-like adjectives are concerned (little, old) but employed with attributive adjectives indicating a spontaneous judgment of the speaker about the person in question. Historically, however, sporadic instances of the syntactically conditioned onymic article can be found in contexts where the article is missing in the modern language, cf. (14):

(14) Geoffrey Chaucer: Canterbury tales, late 14th century

Wel knew he the olde Esculapius,

And Deyscorides, and eek Rufus,

Old Ypocras [...]

Names of rivers require the onymic article (the Thames, the Rhine), which is already attested in Middle English but has not yet become obligatory before the Early Modern English period, thus differing from the situation in Middle Dutch and Middle High German (cf. Hewson 1972: 18-20), cf. (15)-(16): ${ }^{23}$

23 Why names of rivers stand out for taking the onymic article so early (i.e. from the Middle Ages on) has remained unexplored. The fact that in English the noun phrase may also be interpreted as elliptic (the Hudson [river]/the [river] Hudson) does not provide a satisfactory answer as the article is missing in similar cases like *the [Mount] Kilimanjaro (cf. also Anderson 2007: 106f.). Neither does this explanation hold for Modern German (der ${ }^{*}$ Fluss] Rhein masc. 'the Rhine', die 
(15) Ranulf Higden: Polychronicon, engl. translation 14th/15th century: wip be Reyne in pe norp side, wip pe Rone in pe est

(16) Bible, King James Version, 1611:

And were baptized of him in Jordan

In sum, the onymic article appears to be most established in German where the syntactically conditioned article is obligatorily used from the Middle High German period onwards disregarding name type and, what is more, the onymic article is currently about to be established in front of personal names. In Dutch, grammaticalisation is less advanced. Similar to German, premodified names take the onymic article obligatorily, whereas personal names remain undetermined with the exception of names for men in southern dialects. Most restrictions have been observed in English, which only allows for the onymic article in combination with names of rivers and, exceptionally, with personal names when combined with non-restrictive adjectives. Comparing the divergent development in all three languages, it is crucial that the functional expansion of onymic articles correlates with the retention or loss of inflectional categories: in modern German, on the one end of the continuum, three categories (case, gender, and number) are expressed. In modern Dutch, only two morphological categories are maintained (gender and number) and only two genders (common and neuter) are distinguished. In addition, article inflection displays more syncretism. In English, on the other end of the spectrum, article inflection got completely lost during the Middle English period.

The present chapter focused mainly on personal names. In the following, more name types (prototypical vs. non-prototypical names) will be taken into account in order to gain a more complete picture of the expansion of the onymic article in modern languages.

\subsection{Prototypical vs. non-prototypical names}

In order to define prototypical vs. non-prototypical names, the distinction between proper nouns (i.e. the lexical category of name) and proper names (i.e. definite NPs referring uniquely to one entity in the world) is crucial (cf. Schlücker/Acker-

[?] Mosel fem. 'the Moselle') or for Modern Dutch (de *[rivier] Rijn/Moezel). Rather, the onymic article as marker of onymic gender has to be conceived of as a classifier in the sense of Nübling (2015, forthc.) (e.g. EN: Hudson [family name] vs. the Hudson [river name], GE Warnow [city name] vs. die Warnow [river name]). 
mann 2017). Prototypical names (name classes) consist of proper nouns (Anna, London), whereas non-prototypical names (name classes) comprise definite NPs with appellative heads (the White House) - often premodifies by proper nouns (Buckingham Palace).

Following the classification provided in Nübling/Fahlbusch/Heuser (2015: 101-105), personal names and, to a lesser extent, also names of cities and countries or continents represent prototypical names in that they make recourse to a specific inventory (proper nouns) thus being maximally distinct from common nouns. More recent name types are rather descriptive in nature, headed by common nouns (descriptors) that indicate the class of objects, e.g. names of institutions (York University), buildings (Westminster Abbey), streets (Baker Street) or mountains (Mount Everest). These appellative heads enhance the use of onymic articles. Crucially, in English, names containing non-proprial heads also remain more often undetermined compared to German and Dutch, cf. (17)-(19):

(17) GE Die Westminster Abbey wurde zwischen 1045 und 1065 erbaut.

DU (De) Westminster Abbey is tussen 1045 en 1065 opgericht.

EN Westminster Abbey was built between 1045 and 1065.

But: The Empire State Building, The World Trade Center

(18) GE Die Baker Street ist eine berühmte Straße in London.

DU De Bakkersstraat is een korte straat in Amsterdam Centrum.

EN Baker Street is a well-known street in the city of London.

(19) GE Der Mount Everest ist der höchste Berg der Erde.

DU De Mount Everest is de hoogste berg ter wereld.

EN Mount Everest is Earth's highest mountain.

Making recourse to a specific inventory, names of countries and continents usually remain undetermined in all three languages, which exceptionally also holds true for premodified names in English (modern Brazil, ancient Rome) ${ }^{24}$ Thus, with the onymic article being restricted to names of rivers and personal names combined with non-restrictive adjectives, English stands out by a very limited use of the

24 The few exceptions concern country names in the plural (die Niederlande, die USA) or with feminine gender (die Ukraine, die Schweiz) and names that originally belonged to other name classes (der Libanon < range of mountains, der Kongo < river) (cf. Thieroff 2000). Nevertheless, the onymic article is increasingly omitted in order to adapt these younger names morphosyntactically to the German system requiring a county name to be gender neuter and undetermined (Nübling 2015). Strikingly, the corresponding country names (may) also exhibit the onymic article in 
onymic article (cf. also Quirk et al. 1999: 288-297 25 ). The onymic article appears to be better established in German and Dutch, where it is obligatorily used with many non-prototypical name types, i.e. names of buildings and institutions or streets. What is more, disregarding name type, the onymic article is required obligatorily with adjectival premodifiers. German stands out by accepting onymic articles with personal names in informal speech in large parts of the German speaking area. See Figure 9 for an overview.

\begin{tabular}{|c|c|c|c|c|}
\hline $\begin{array}{l}\text { buildings, } \\
\text { institutions }\end{array}$ & $\begin{array}{l}\text { streets, rivers, } \\
\text { mountains }\end{array}$ & $\begin{array}{l}\text { countries, } \\
\text { continents }\end{array}$ & cities & persons \\
\hline \multicolumn{5}{|l|}{ German } \\
\hline \multirow[t]{2}{*}{$\begin{array}{l}\text { die Paulskirche } \\
\text { die Goetheschule }\end{array}$} & \multirow[t]{2}{*}{$\begin{array}{l}\text { die Goethestraße } \\
\text { der Rhein, der K2 }\end{array}$} & Italien, Asien & Mainz, Paris & $\begin{array}{l}\text { Anna, Jan, coll.: } \\
\text { die Anna, der Jan }\end{array}$ \\
\hline & & das ferne Asien & das alte Rom & der große Jan \\
\hline \multicolumn{5}{|l|}{ Dutch } \\
\hline \multirow[t]{2}{*}{$\begin{array}{l}\text { de St. Nicolaas- } \\
\text { basiliek } \\
\text { de Tower Bridge }\end{array}$} & \multirow[t]{2}{*}{$\begin{array}{l}\text { de Hoofdstraat } \\
\text { de Mount Everest } \\
\text { de Rijn, de } \\
\text { Moezel }\end{array}$} & Italië, Azië & $\begin{array}{l}\text { Amsterdam, } \\
\text { Parijs }\end{array}$ & $\begin{array}{l}\text { Jan, Emma } \\
\text { (Flemish: de Jan) }\end{array}$ \\
\hline & & $\begin{array}{l}\text { het zonnige } \\
\text { Frankrijk }\end{array}$ & het mooje Parijs & de kleine Jan \\
\hline \multicolumn{5}{|l|}{ English } \\
\hline \multirow{2}{*}{$\begin{array}{l}\text { Tower Bridge, } \\
\text { Westminster } \\
\text { Abbey }\end{array}$} & $\begin{array}{l}\text { Madison Avenue, } \\
\text { Mount Everest }\end{array}$ & $\begin{array}{l}\text { Italy, France, } \\
\text { Asia, Europe }\end{array}$ & London, Paris & Anna, James \\
\hline & $\begin{array}{l}\text { the Rhine, } \\
\text { the (River) } \\
\text { Thames }\end{array}$ & modern Brazil & ancient Rome & $\begin{array}{l}\text { little James, but: } \\
\text { the unfortunate } \\
\text { James }\end{array}$ \\
\hline
\end{tabular}

Fig. 9: Usage of onymic articles in German, Dutch, and English considering different name classes

English (*(the) USA, (the) Sudan, (the) Ukraine) (cf. Quirk et al. 1999: 293). As prototypical English country names are all undetermined (England, France, Italy), the article is also likely to be omitted in the long run.

25 For a corpus-based investigation of article usage with complex or "multi-word" names in English see Tse (2005). 
Further aspects that have not yet been considered in the present study but that appear to be relevant for the languages investigated concern, on the one hand, obligatoriness or, more precisely, interchangeability of the definite article and the possessive pronoun (when referring to body parts, for example) and, on the other hand, formal reduction, i.e. the occurrence of clitic forms. The following section provides first observations in these respects.

\subsection{Obligatoriness: Possessive pronoun vs. definite article}

The use of possessive pronouns vs. definite articles completes the general picture presented here according to which English represents an earlier stage in grammaticalisation. In combination with body parts, the possessive pronoun is preferred in modern English (He closed his eyes/?the eyes), which parallels the situation in Old High German where possessive pronouns likewise constitute the first choice. In Middle High German, both vary freely, whereas on the way to New High German the definite article has taken over. In modern Dutch, both options are still available, but the possessive pronoun is clearly preferred (Hij sluit zijn ogen/?de ogen). Thus, diachronic variation in German seems to be paralleled by synchronic variation in the three languages considered, cf. (20)-(21) (bold print is used for the preferred variant):

(20) Diachronic variation:

OHG: Tatian

$\begin{array}{lllllll}\text { leimon teta } & \text { hér } & \text { mir } & \text { ubar minu ougun } \\ \text { balm gave ("did") } & \text { he } & \text { to me } & \text { on } & \text { my } & \text { eyes }\end{array}$

MHG: Herbort von Fritzlar: Liet von Troye (a), Konrad v. Würzburg: Trojanerkrieg (b)
a. sine ougen er vf hup his eyes he raised up
b. sie reip diu ougen unde sprach

she rubbed her eyes and spoke

NHG

er schloss seine / die Augen
he closed his / the 'his' eyes

(21) Synchronic variation

EN He closed his eyes/*the eyes.

DU Hij sluit zijn ogen/?de ogen.

GE Er schloss seine Augen/die Augen. 
This first impression fits well into the general picture of article grammaticalisation, however, corpus data needs to be provided in future research.

\subsection{Formal reduction}

Formal reduction is known as a typical side effect of increasing semantic bleaching during the process of grammaticalisation, a notion often referred to as 'form follows function'. Accordingly, clitic or suffixed definiteness markers are expected in languages representing later stages of grammaticalisation (cf. Lehmann 1995: 59; van Gelderen 2007 on the definiteness cycle in Germanic). Coexisting with more recent free forms, suffixed articles represent a characteristic feature of Scandinavian languages (e.g. Swedish ett hus 'a house' vs. hus-et house-def. 'the house') (Dahl 2004; Askedal 2011). Among the three West Germanic languages considered, clitic articles are most prominent in German where masculine and neuter definite articles clitisise to the preposition (zum Arzt 'to=the-MASc doctor', durch's Fenster 'through=the-NEUT window'). With highly frequent, monosyllabic prepositions (e.g. in 'in', $z u$, 'to', an 'on'), enclitic articles are obligatory and no longer interchangeable with their corresponding free forms without a change in meaning (Nübling 1992, 1998), cf. (22)-(24):

(22) Sie ist im Kino.

'She is in=the cinema.'

Sie ist in dém Kino, das ich so gerne mag.

'She is in the cinema that I like so much.'

(23) Sie ist im Urlaub / Sie ist in *dem Urlaub.

She is in=the vacation / She is in *the vacation.

'She is on vacation.'

(24) Sie macht eine Ausbildung zur (> zu einer/*der)

She makes a training to $=$ the ( $>$ to $a /{ }^{\star}$ the)

Krankenschwester

nurse

'She is trained as a nurse'

Whereas in (22) the clitic article may denote either a definite or an indefinite entity, in (23)-(24) only an indefinite/generic reading is possible, and the clitic is no longer interchangeable with the free form. Clitic articles are already attested for Old and Middle High German (cf. Waldenberger 2009), but are most extensively used in Early Modern German (cf. Christiansen 2016). In Dutch, clitics are characteristic of Middle Dutch where both proclitic and enclitic articles, attached to the 
noun (dat/het $>d$, $t$ : tkint the=child, $d$ water the=water) and attached to prepositions (int < in dat/het 'in the-neut.'), respectively, are attested (cf. van Loey 1970: 145f.; van der Horst 2008, I: 388f.). ${ }^{26}$ In Modern Dutch, enclitics (preposition= article) subsist in informal speech giving rise to head-marked prepositions similar to German (e.g. Ik zag haar in't museum; cf. van Gelderen 2007). In English, the invariant definite article is not the object of formal reduction; clitic forms are not attested in modern (standard) English. In earlier stages, however, proclitics do appear, especially in Early Modern English texts and, archaically, also later where the is regularly reduced to th in front of vowels and $h$ (th' enemy, th' hilt) and some consonants (th' world, th' miller) (cf. Poutsma 1914: 513f.; van Gelderen 2007). With enclitics being attested in Dutch and particularly in German but not in English, the observable formal reduction reflects, at first glance, the extent of functional expansion. Unlike their Scandinavian counterparts, restrictions in use are, however, twofold - at least in standard varieties: syntactically to prepositional phrases (PP) and morphologically, to masculine/neuter (German) and neuter (Dutch) gender respectively, see Figure 10:

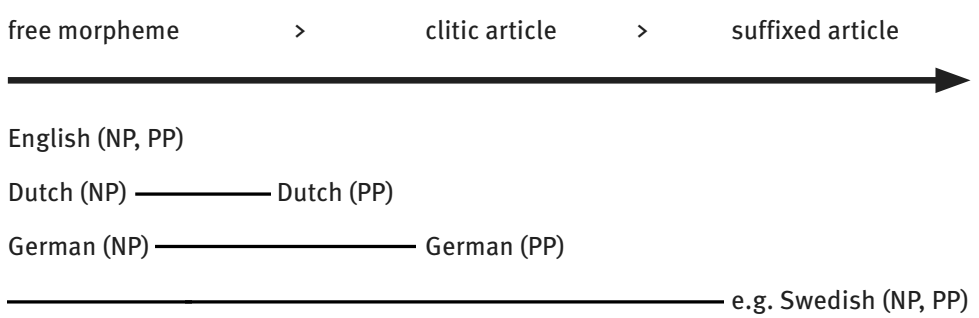

Fig. 10: Formal reduction of definite articles

\section{Summary}

The investigation of definite articles in three West Germanic languages revealed that the grammaticalisation and functional expansion that occurred independently in each of them, still follows the same underlying hierarchy presented in Figure 11:

26 The fact that definite articles occurred regularly as clitics in Middle Dutch explains the modern form of the neuter article het (instead of dat): Clitic t' has erroneously been associated with the neuter pronoun het and, as a consequence, former dat was replaced by het on the way to modern Dutch (van Loey 1970: 145f.). 




functional expansion

Fig. 11: Functional expansion of definite articles in Germanic

In all three languages investigated, the definite article may denote individual referents that are part of the shared pragmatic set (e.g. general knowledge, a prior conversation) and are as such identifiable by the hearer and thus markers of definiteness in a strict sense (Stage I articles). Generic reference, as a next step in Lyons' (1999) "hierarchy" of diachronic expansion, acts insofar as a first obstacle as, in all three languages, the generic article is well established only in the singular when referring to kinds (the tiger/de tijger/der Tiger) but restricted in use with mass nouns, which usually remain undetermined in English and Dutch $\left({ }^{*}\right.$ the riz/??de rijst - der Reis), see Figure 12.

\begin{tabular}{|c|c|c|c|c|}
\hline $\begin{array}{l}\text { I } \\
\text { DEfINITE } \\
\text { animate > } \\
\text { concrete> } \\
\text { abstract }\end{array}$ & $\begin{array}{l}\text { II } \\
\text { GENERIC } \\
\text { singular > }\end{array}$ & : plural & $\begin{array}{l}\text { III } \\
\text { ONYMIC } \\
\text { + premodified > } \\
\text { - prototypical > }\end{array}$ & $\begin{array}{l}\vdots \text { - premodified } \\
\vdots \text { + prototypical }\end{array}$ \\
\hline \multicolumn{5}{|l|}{ English } \\
\hline $\begin{array}{l}\text { the woman } \\
\text { the book } \\
\text { the freedom }\end{array}$ & $\begin{array}{l}\text { the tiger } \\
\text { *the rice } \\
\text { in *the spring }\end{array}$ & $\begin{array}{l}\text { ?the citizens } \\
\text { ??the Americans } \\
\text { *the books }\end{array}$ & $\begin{array}{l}\text { *the ancient Rome } \\
\text { *the little Mary }\end{array}$ & $\begin{array}{l}\text { the Rhine } \\
\text { the Mount Everest } \\
\text { *the Baker Street } \\
\vdots \text { *the Mary }\end{array}$ \\
\hline \multicolumn{5}{|l|}{ Dutch } \\
\hline $\begin{array}{l}\text { de vrouw } \\
\text { het boek } \\
\text { de vrijdom }\end{array}$ & $\begin{array}{l}\text { de tijger } \\
\text { de rijst } \\
\text { in de lente }\end{array}$ & $\begin{array}{l}\text { de burgers } \\
\text { de Amerikanen } \\
\vdots \text { *de boeken }\end{array}$ & $\begin{array}{l}\text { het oude Rome } \\
\text { de kleine Jan } \\
\text { [Zwarte Piet] }\end{array}$ & $\begin{array}{l}\text { de Rijn } \\
\text { de Mount Everest } \\
\text { de Bakkerstraat } \\
\text { ??de Jan, * de Emma }\end{array}$ \\
\hline \multicolumn{5}{|l|}{ German } \\
\hline $\begin{array}{l}\text { die Frau } \\
\text { das Buch } \\
\text { die Freiheit }\end{array}$ & $\begin{array}{l}\text { der Tiger } \\
\text { der Reis } \\
\text { im Frühling }\end{array}$ & $\begin{array}{l}\text { die Bürger } \\
\text { die Amerikaner } \\
: \text { *die Bücher }\end{array}$ & $\begin{array}{l}\text { das alte Rom } \\
\text { der kleine Jan }\end{array}$ & $\begin{array}{l}\text { der Rhein } \\
\text { der Mount Everest } \\
\text { der Jan (coll.) }\end{array}$ \\
\hline
\end{tabular}

Fig. 12: Stages in grammaticalisation of definite articles in English, Dutch, and German 
Definite generics appear to be even more restricted in the plural for mainly two reasons. First, definite plural generics are principally only available for animate referents (die Bürger/die Amerikaner/ ${ }^{*}$ die Bücher, de burgers/?de Amerikanen/* de boeken). Second, being more strongly associated with kind-reference, definite (plural) generics (most common with nationality terms) tend to involve a negative reading and the notion of "othering" - a connotation which is most prevalent in English (the citizens/??the Americans), with bare plurals representing the unmarked option (??the African-Americans/African-Americans).

Onymic articles, i.e. definite articles combined with inherently definite proper names, constitute the third and so far final stage of extension in the languages considered. They establish first in combination with premodifiers for syntactical reasons. Syntactically conditioned onymic articles are already common in Middle High German and in Middle Dutch, but until now absent in English (das alte Rom/het oude Rome/*the ancient Rome). For the spread of the onymic article to unmodified names, the presence/absence of appellative heads turned out to be crucial in that rather descriptive names and names with an appellative basic level term (e.g. names of streets and institutions) take the onymic article more readily than prototypical names (e.g. names of persons and cities) (e.g. DU de Hoofdstraat vs. ${ }^{*}$ de Emma, GE die Hauptstraße vs. ??die Emma). Apart from that, name class has been identified as a decisive factor (EN ${ }^{*}$ the Queen Mary (person) vs. the Queen Mary (ship); DU * de Koningin Mary vs. de Queen Mary). In English, proper names remain undetermined in most cases, which also holds true for many non-prototypical names with appellative heads (e.g. *the Bakerstreet, ${ }^{*}$ the Mount Everest - but the [River] Thames, the Atlantic [Ocean]). Strikingly, the limited use of onymic articles in English as compared to Dutch and German parallels the situation with semantically definite uniques, where the expletive definite article likewise occurs less consistently ( ${ }^{*}$ the heaven, ${ }^{*}$ the paradise, (the) earth) and, accordingly, is best described as a definiteness marker in a strict sense. In German, at the other end of the continuum, the functional expansion is most advanced, as, in large parts (Central and South German), the onymic article also combines with personal names in informal speech. As has been shown, personal names preceded by an onymic article are not a unknown feature in Dutch, either, but limited to southern dialects and to names of men. 


\section{References}

ANS = Walter Haeseryn (ed.) (1997): Algemene Nederlandse spraakkunst. 2nd edition. Groningen: Martinus Nijhoff Uitgevers.

Anderson, John M. (2007): The grammar of names. Oxford: Oxford University Press.

Askedal, John Ole (2011): The Germanic languages. In: Kortmann, Bernd/van der Auwera, Johan (eds.): The languages and linguistics of Europe: A comprehensive guide. (= The World of Linguistics 1). Berlin/Boston: De Gruyter. 47-68.

Barton, Dagmar/Kolb, Nadine/Kupisch, Tanja (2015): Definite article use with generic reference in German: An empirical study. In: Zeitschrift für Sprachwissenschaft 34, 2. 147-173.

Behaghel, Otto (1923): Deutsche Syntax. Eine geschichtliche Darstellung. Vol. 1: Die Wortklassen und Wortformen. A: Nomen, Pronomen. Heidelberg: Winter.

Behrens, Leila (2000): Typological parameters of genericity. Köln: Institut für Sprachwissenschaft. Bellmann, Günter (1990): Pronomen und Korrektur: Zur Pragmalinguistik der persönlichen Referenzformen. Berlin/New York: De Gruyter.

Blake, Norman F. (ed.) (1992): The Cambridge history of the English language. Vol. 2: 1066-1476. Cambridge: Cambridge University Press.

Carlson, Gregory N. (1978): Reference to kinds in English. Bloomington, IN: Indiana University Linguistics Club.

Carlson, Gregory N./Pelletier, Francis Jeffry (eds.) (1995): The generic book. Chicago/London: University of Chicago Press.

Chesterman, Andrew (1991): On definiteness: A study with special reference to English and Finnish. (= Cambridge Studies in Linguistics 56). Cambridge: Cambridge University Press.

Christiansen, Mads (2016): Von der Phonologie in die Morphologie: Diachrone Studien zur Präposition-Artikel-Enklise im Deutschen. (= Germanistische Linguistik 32). Hildesheim et al.: Olms.

Christophersen, Paul (1939): The articles. A study of their theory and use in English. Copenhagen: Munksgaard.

COW-Corpus: http://corporafromtheweb.org/ (last accessed: 3-7-2019).

Curme, George 0. (1922): A grammar of the German language. Designed for a thoro and practical study of the language as spoken and written to-day. New York et al.: Macmillan.

Dahl, Östen (2004): Definite articles in Scandinavian: Competing grammaticalization processes in standard and non-standard varieties. In: Kortmann, Bernd (ed.): Dialectology meets typology. Dialect grammar from a cross-linguistic perspective. (= Trends in Linguistics: Studies and Monographs 153). Berlin/New York: De Gruyter. 147-180.

Debus, Friedhelm/Heuser, Rita/Nübling, Damaris (eds.) (2014): Linguistik der Familiennamen. (= Germanistische Linguistik 225-227). Hildesheim et al.: Olms.

Dryer, Matthew S. (1989): Article-noun order. In: Chicago Linguistic Society/Wiltshire, Caroline/Graczyk, Randolph/Music, Bradley (eds.): Papers from the 25th Annual Regional Meeting of the Chicago Linguistic Society, part one: The general session. 83-97.

Duden (2016) $=$ Der Duden in zwölf Bänden. Vol. 4: Die Grammatik. Unentbehrlich für richtiges Deutsch. Mannheim et al.: Dudenverlag.

Eichhoff, Jürgen (2000): Wortatlas der deutschen Umgangssprachen. Vol. 4. Berlin: De Gruyter. Flick, Johanna (2017): Die Entwicklung des Definitartikels im Deutschen. Eine kognitivlinguistische Korpusuntersuchung. Diss. Univ. Hamburg. 
Flick, Johanna/Szczepaniak, Renata (eds.) (forthc.): Walking on the grammaticalization path of the definite article in German: Functional main and side roads. Amsterdam/Philadelphia: Benjamins.

Gallmann, Peter (1997): Zur Morphosyntax der Eigennamen im Deutschen. In: Löbel, Elisabeth/ Rauh, Gisa (eds.): Lexikalische Kategorien und Merkmale. (= Linguistische Arbeiten 366). Tübingen: Niemeyer. 73-86.

Gerstner Claudia/Krifka, Manfred (1993): Genericity. In: Jacobs, Joachim/Stechow, Arnim von/ Sternefeld, Wolfgang/Vennemann, Theo (eds.): Syntax. An international handbook of contemporary research. Vol 1. (= Handbücher zur Sprach- und Kommunikationswissenschaft/Handbooks of Linguistics and Communication Science 9). Berlin/New York: De Gruyter. 966-978.

Greenberg, Joseph H. (1978): How does a language acquire gender markers? In: Greenberg, Joseph H./Ferguson, Charles A./Moravcsik, Edith (eds.): Universals of human language. Stanford, CA: Stanford University Press. 47-82.

Harris, Martin B. (1980): The marking of definiteness: A diachronic perspective. In: Traugott, Elizabeth C./Labrum, Rebecca/Shepherd, Susan C. (eds.): Papers from the Fourth International Conference on Historical Linguistics, Standford, March 26-30 1979. (= Current Issues in Linguistic Theory 14). Amsterdam: Benjamins. 75-86.

Haspelmath, Martin (1998): How young is Standard Average European? In: Language Sciences 20, 3. 271-87.

Haspelmath, Martin (2001): The European linguistic area: Standard Average European. In: Haspelmath, Martin et al. (eds.): Language typology and language universals/Sprachtypologie und sprachliche Universalien/La typologie des langues et les universaux linguistiques. Vol. 2. (= Handbücher zur Sprach- und Kommunikationswissenschaft/ Handbooks of Linguistics and Communication Science 20). Berlin/New York: De Gruyter. 1492-1510.

Hawkins, John A. (1978): Definiteness and indefiniteness: A study in reference and grammaticality prediction. Atlantic Highlands, NJ: Humanities Press.

Hawkins, John A. (1991): On (in)definite articles: Implicatures and (un)grammaticality prediction. In: Journal of Linguistics 27, 2. 405-442.

Hawkins, John A. (2004): Efficiency and complexity in grammars. Oxford: Oxford University Press. Heine, Bernd/Kuteva, Tania (2006): The changing languages of Europe. Oxford: Oxford University Press.

Hewson, John (1972): Article and noun in English. (= Janua Linguarum: Series Practica 104). The Hague: Mouton.

Himmelmann, Nikolaus P. (1997): Deiktikon, Artikel, Nominalphrase. Zur Emergenz syntaktischer Struktur. (= Linguistische Arbeiten 362). Tübingen: Niemeyer.

Himmelmann, Nikolaus P. (2001): Articles. In: Haspelmath, Martin et al. (eds.): Language typology and language universals/Sprachtypologie und sprachliche Universalien/La typologie des langues et les universaux linguistiques. Vol. 1. (= Handbücher zur Sprachund Kommunikationswissenschaft/Handbooks of Linguistics and Communication Science 20). Berlin/New York: De Gruyter. 831-841.

Hodler, Werner (1954): Grundzüge einer germanischen Artikellehre. (= Germanistische Bibliothek 3). Heidelberg: Winter.

Hogg, Richard M. (ed.) (1992): The Cambridge history of the English language. Vol. 1: The beginnings to 1066. Cambridge: Cambridge University Press. 
Hopper, Paul J. (1990): Principles of grammaticization: Towards a diachronie typology. In: Lehmann, Winfred P. (ed.): Language typology 1987. Systematic balance in language. (= Current Issues in Linguistic Theory 67). Amsterdam/Philadelphia: Benjamins. 157-170. Hopper, Paul J. (1991): On some principles of grammaticalization. In: Traugott, Elisabeth C./ Heine, Bernd (ed.): Approaches to grammaticalization. Vol. 1: Focus on theoretical and methodological issues. (= Typological Studies in Language 19). Amsterdam/Philadelphia: Benjamins. 17-35.

Huddleston, Rodney D./Pullum, Geoffrey K. (2002): The Cambridge grammar of the English language. Cambridge: Cambridge University Press.

Karnowski Pawet/Pafel, Jürgen (2005): Wie anders sind Eigennamen? In: Zeitschrift für Sprachwissenschaft 24, 1. 45-66.

König, Ekkehard (2018): Definite articles and their uses. In: Van Olmen, Daniël/Mortelmans, Tanja/Brisard, Frank (eds.): Aspects of linguistic variation. (= Trends in Linguistics: Studies and Monographs 324). Berlin/Boston: De Gruyter. 165-184.

Kortmann, Bernd (1997): Adverbial subordination: A typology and history of adverbial subordinators based on European languages. (= Empirical Approaches to Language Typology 18). Berlin/New York: De Gruyter.

Kratzer, Angelika (1995): Stage-level and individual-level predicates. In: Carlson/Pelletier (eds.). 125-175.

Krifka, Manfred (2004): Bare NPs: Kind-referring, indefinites, both, or neither? In: Bonami, Olivier/Cabredo Hofherr, Patricia (eds.): Empirical issues in formal syntax and semantics 5. 111-132. http://www.cssp.cnrs.fr/eiss5/krifka/krifka-eiss5.pdf (last accessed: 3-7-2019).

Krifka, Manfred (2012): Definitional generics. In: Mari/Beyssade/Del Prete (eds.). 372-389.

Krifka, Manfred/Pelletier, Francis Jeffry/Carlson, Gregory N./ter Meulen, Alice/Chierchia, Gennaro/Link, Godehard (1995): Genericity: An introduction. In: Carlson/Pelletier (eds.). 1-125.

Kupisch, Tanja/Barton/Dagmar (2013): Generic reference in adult German bilinguals: How bilinguals deal with variation. In: Studia Linguistica 67, 1. 1-27.

Kupisch, Tanja/Pierantozzi, Cristina (2010): Interpreting definite plural subjects: A comparison of German and Italian monolingual and bilingual children. In: Franich, Katie/Iserman, Kate M./ Keil, Lauren L. (eds.): Proceedings of the 34th annual Boston University Conference on Language Development (BUCLD 34). Vol. 1. Somerville, MA: Cascadilla Press. 245-254.

Laca, Brenda (1992): Studien zur Generizität. Kontrastive Untersuchungen zur Artikeldistribution und zur Semantik „,generischer“ Nominalphrasen. Diss. Berlin.

Lass, Roger (ed.) (1999): The Cambridge history of the English language. Vol. 3: 1476-1776. Cambridge: Cambridge University Press.

Lehmann, Christian (1995): Thoughts on grammaticalization. (= LINCOM Studies in Theoretical Linguistics 1). Munich/New Castle: LINCOM Europa.

Leiss, Elisabeth (2000): Artikel und Aspekt. Die grammatischen Muster von Definitheit. (= Studia Linguistica Germanica 55). Berlin/New York: De Gruyter.

Löbner, Sebastian (1985): Definites. In: Journal of semantics 4, 4. 279-326.

Longobardi, Giuseppe (1994): Reference and proper names: A theory of N-movement in syntax and logical form. In: Linguistic Inquiry 25, 4. 609-665.

Lyons, Christopher G. (1980): The meaning of the English definite article. In: van der Auwera (ed.). 81-95.

Lyons, Christopher G. (1991): English nationality terms: Evidence for dual category membership. In: Journal of Literary Semantics 20, 2. 97-116. 
Lyons, Christopher G. (1999): Definiteness. Cambridge: Cambridge University Press.

Mari, Alda/Beyssade, Claire/Del Prete, Fabio (eds.) (2012): Genericity. Oxford: Oxford University Press.

Mulder, Walter de/Carlier, Anne (2011): The grammaticalization of definite articles. In: Narrog, Heiko/Heine, Bernd (eds.): The Oxford handbook of grammaticalization. Oxford: Oxford University Press. 522-534.

Nickel, Bernhard (2012): Dutchmen are good sailors: Generics and gradability. In: Mari/Beyssade/ Del Prete (eds.). 390-405.

Nübling, Damaris (1992): Klitika im Deutschen - Schriftsprache, Umgangssprache, alemannische Dialekte. (= ScriptOralia 42). Tübingen: Narr.

Nübling, Damaris (1998): Wann werden die deutschen Präpositionen flektieren? Grammatisierungswege zur Flexion. In: Fabri, Ray/Ortmann, Albert/Parodi, Teresa (eds.): Models of inflection. (= Linguistische Arbeiten 388). Tübingen: Niemeyer. 266-289.

Nübling, Damaris (2015): Die Bismarck - der Arena - das Adler. Vom Drei-Genus- zum SechsKlassen-System bei Eigennamen im Deutschen: Degrammatikalisierung und Exaptation. In: Zeitschrift für Germanistische Linguistik 43, 2. 306-344.

Nübling, Damaris (forthc.): Die Bismarck - der Arena - das Adler. The emergence of a classifier system for proper names in German. In: Flick/Szczepaniak (eds.) (forthc.).

Nübling, Damaris/Fahlbusch, Fabian/Heuser, Rita (2015): Namen. Eine Einführung in die Onomastik. 2nd revised and extended edition. Tübingen: Narr.

Oosterhof, Albert (2008): The semantics of generics in Dutch and related languages. (= Linguistik aktuell/Linguistics Today 122). Amsterdam/Philadelphia: Benjamins.

Oubouzar, Erika (1992): Zur Ausbildung des bestimmten Artikels im Althochdeutschen. In: Desportes, Yvon (ed.): Althochdeutsch. Syntax und Semantik. Akten des Lyonner Kolloquiums zur Syntax und Semantik des Althochdeutschen (1-3 März 1990). (= Série Germanique Ancien 1). Lyon: Centre d'Etudes Linguistiques Jaques Goudet. 69-87.

Oubouzar, Erika (1997): Zur Frage der Herausbildung eines bestimmten und eines unbestimmten Artikels im Althochdeutschen. In: Cahiers d'Études Germaniques 32. 161-175.

Paul, Hermann (1919): Deutsche Grammatik. Vol. 3. Part 4: Syntax. Halle a.d.S.: Niemeyer.

Platteau, Frank (1980): Definite and indefinite generics. In: van der Auwera (ed.). 112-123.

Poutsma, Hendrik (1914): A grammar of late modern English. For the use of continental, especially Dutch students. Vol. 2. Part 1a: Nouns, adjectives and articles. Groningen: Noordhoff.

Quirk, Randolph/Greenbaum, Sidney/Leech, Geoffrey/Svartvik, Jan (1999): A comprehensive grammar of the English language. London et al.: Longman.

Schaden, Gerhard (2012): Two ways of referring to generalities in German. In: Mari/Beyssade/ Del Prete (eds.). 157-175.

Schäfer, Roland (2015): Processing and querying large web corpora with the COW14 architecture. In: Bański, Piotr/Biber, Hanno/Breiteneder, Evelyn/Kupietz, Marc/Lüngen, Harald/Witt, Andreas (eds.): Proceedings of the 3rd Workshop on Challenges in the Management of Large Corpora (CMLC-3). Mannheim: Institut für Deutsche Sprache. 28-34.

Schäfer, Roland/Bildhauer, Felix (2012): Building large corpora from the web using a new efficient tool chain. In: Calzolari, Nicoletta/Choukri, Khalid/Declerck, Thierry/Doğan, Mehmet Uğur/ Maegaard, Bente/Mariani, Joseph/Moreno, Asuncion/Odijk, Jan/Piperidis, Stelios (eds.): Proceedings of the Eighth International Conference on Language Resources and Evaluation (LREC 2012). Paris: European Language Resources Association. 486-493.

Schlücker, Barbara/Ackermann, Tanja (2017): The morphosyntax of proper names: An overview. In: Folia Linguistica 51, 2. 309-339. 
Schmuck, Mirjam (forthc.): The rise of the onymic article in Early New High German - areal factors and the triggering effect of bynames. In: Flick/Szczepaniak (eds.) (forthc.).

Schmuck, Mirjam/Szczepaniak, Renata (2014): Der Gebrauch des Definitartikels vor Familien- und Rufnamen im Frühneuhochdeutschen aus grammatikalisierungstheoretischer Perspektive. In: Debus/Heuser/Nübling (eds.). 97-137.

Schroeder, Christoph (2006): Articles and article systems in some areas of Europe. In: Bernini, Giuliano/Schwartz, Marcia L. (eds.): Pragmatic organization of discourse in the languages of Europe. (= Empirical Approaches to Language Typology 8). Berlin/New York: De Gruyter. 545-611.

Sturm, Afra (2005): Eigennamen und Definitheit. (= Linguistische Arbeiten 498). Tübingen: Niemeyer.

Szczepaniak, Renata (2011): Grammatikalisierung im Deutschen. Eine Einführung. 2nd edition. Tübingen: Narr.

Szczepaniak, Renata/Flick, Johanna (2015): Zwischen Explizitheit und Ökonomie - Der emergierende Definitartikel in der althochdeutschen Isidor-Übersetzung. In: Pasques, Delphine (ed.): Komplexität und Emergenz in der deutschen Syntax (9.-17. Jahrhundert). Akten zum Internationalen Kongress an der Universität Paris-Sorbonne vom 26. bis 28.09.2013. (= Berliner sprachwissenschaftliche Studien 30). Berlin: Weidler. 187-206.

Thieroff, Rolf (2000): *Kein Konflikt um Krim. Zu Genus und Artikelgebrauch von Ländernamen. In: Hess-Lüttich, Ernest W. B./Schmitz, H. Walter (eds.): Botschaften verstehen. Kommunikationstheorie und Zeichenpraxis. Frankfurt a.M. et al.: Lang. 271-284.

Tse, Grace Y. W. (2005): A corpus-based study of proper names in present-day English: Aspects of gradience and article usage. (= English Corpus Linguistics 2). Frankfurt a.M. et al.: Lang. van Gelderen, Elly (2007): The definiteness cycle in Germanic. In: Journal of Germanic Linguistics 19, 4. 275-308.

van de Ven, M.H./Govaart, W. (1917): Nogmaals DE voor eigennamen. In: De Nieuwe Taalgids 11. 188-194.

van der Horst, Joop (2008): Geschiedenis van de Nederlandse syntaxis. 2 volumes. Leuven: Univ. Pers Leuven.

van der Auwera, Johan (ed.) (1980): The semantics of determiners. London: Croom Helm.

van Langendonck, Willy (2007): Theory and typology of proper names. (= Trends in Linguistics. Studies and Monographs 168). Berlin/Boston: De Gruyter.

van Loey, Adolphe (1970): Schönfeld's historische grammatica van het Nederlands: Klankleer, vormleer, woordvorming. 8th edition. Zuthpen: Thieme.

van Loon, Jozef (1989): Een peiling naar het ontstaan van het Zuidnederlandse accusativisme. In: Tijdschrift voor Nederlandse Taal- en Letterkunde 105. 209-223.

Waldenberger, Sandra (2009): Präpositionen und Präpositionalphrasen im Mittelhochdeutschen. (= Studien zur mittelhochdeutschen Grammatik 3). Tübingen: Niemeyer.

Wandruszka, Mario (1969): Sprachen: Vergleichbar und unvergleichlich. Munich: Piper. Werth, Alexander (2014): Die Funktionen des Artikels bei Personennamen im norddeutschen Sprachraum. In: Debus/Heuser/Nübling (eds.). 139-174.

Werth, Alexander (2015): Kasusmarkierung bei Personennamen in deutschen Regionalsprachen. In: Lenz, Alexandra N./Patocka, Franz (eds.): Syntaktische Variation: Areal-linguistische Perspektiven. (= Wiener Arbeiten zur Linguistik 2). Göttingen: Vandenhoeck \& Ruprecht. 199-218. 